\title{
Hepatoprotective Effect of Sun Chlorella as an Antioxidant in Rattus norvegicus Induced Carbon Tetrachloride
}

\author{
Wahyu Siswandari, ${ }^{1}$ Fitranto Arjadi, ${ }^{2}$ Hernayanti, ${ }^{3}$ Vitasari Indriani ${ }^{1}$ \\ ${ }^{1}$ Department of Clinical Pathology, Faculty of Medicine, Universitas Jenderal Soedirman, Purwokerto, Indonesia, \\ ${ }^{2}$ Department of Anatomy, Faculty of Medicine, Universitas Jenderal Soedirman, Purwokerto, Indonesia, \\ ${ }^{3}$ Department of Ecotoxicology, Faculty of Biology, Universitas Jenderal Soedirman, Purwokerto, Indonesia
}

\begin{abstract}
Carbon tetrachloride $\left(\mathrm{CCl}_{4}\right)$ is a chemical that can cause damage to liver cells. One of the natural ingredients developed to reduce liver damage due to chemicals and infections is Chlorella sp. The research aimed to explore the hepatoprotective effect of the antioxidant superoxide dismutase (SOD) by administering Sun Chlorella in Rattus norvegicus $\mathrm{CCl}_{4}$ induced rats. The study design used a post-test with a control group design with a completely randomized design trial on 30 male rats of Wistar strains, aged 2-3 months, 200-250 grams in weight. The research was conducted in November 2016-January 2017 in Purwokerto. Rats were divided into five groups and treated for four weeks as follows: $\mathrm{K} 1$ group was given aquades; $\mathrm{K} 2$ was given $\mathrm{CCl}_{4} ; \mathrm{K}_{3}, \mathrm{~K}_{4}, \mathrm{~K}_{5}$ were given $\mathrm{CCl}_{4}$ and $\mathrm{Sun}$ Chlorella $3.6 \mathrm{mg} / 200 \mathrm{gBW}, 7.2 \mathrm{mg} / 200 \mathrm{gBW}$, and $14.4 \mathrm{mg} / 200 \mathrm{gBW}$ respectively, by the gastric probe. Statistical analysis with correlation test and one way ANOVA multivariate test showed that Sun Chlorella 7.2 and 14.4 mg/200 gBW significantly increased SOD levels in rats induced $\mathrm{CCl}_{4}(\mathrm{p}=0.004, \mathrm{p}=0.009)$. SOD rates were significantly strong associated with aspartate aminotransferase/AST $(\mathrm{r}=-0.685, \mathrm{p}=0.000)$ and alanine aminotransferase/ALT $(\mathrm{r}=-0.659, \mathrm{p}=0.000)$. The conclusion is Sun Chlorella increases SOD levels in $\mathrm{CCl}_{4}$-induced rats. Increased SOD levels may decrease AST and ALT levels.
\end{abstract}

Key words: Antioxidant, $\mathrm{CCl}_{4}$, Chlorella, $\mathrm{SOD}$

\section{Efek Hepatoprotektif Sun Chlorella sebagai Antioksidan pada Rattus norvegicus yang Diinduksi Karbon Tetraklorida}

\begin{abstract}
Abstrak
Karbon tetraklorida $\left(\mathrm{CCl}_{4}\right)$ merupakan bahan kimia yang dapat menyebabkan kerusakan sel hati. Berbagai bahan alami telah dikembangkan untuk mengurangi kerusakan hati baik akibat bahan kimia maupun infeksi, salah satunya adalah Chlorella sp. Penelitian ini bertujuan melihat efek hepatoprotektif dengan pemberian Sun Chlorella pada tikus Rattus norvegicus yang diinduksi $\mathrm{CCl}_{4}$. Desain penelitian menggunakan post-test with a control group dengan rancangan percobaan rancangan acak lengkap pada 30 tikus jantan galur Wistar, usia 2-3 bulan, dan berat 200-250 gram. Penelitian ini dilakukan di Purwokerto pada periode November 2016-Januari 2017. Tikus dibagi menjadi lima kelompok dan mendapatkan perlakuan per oral dengan sonde lambung selama 4 minggu sebagai berikut: kelompok K1 sebagi kontrol negatif diberikan aquades; kelompok control positif $\mathrm{K} 2$ diberikan $\mathrm{CCl}_{4}$; kelompok perlakuan $\mathrm{K}_{3}, \mathrm{~K} 4$, dan $\mathrm{K}_{5}$ diberikan $\mathrm{CCl}_{4}$ dan Sun Chlorella 3,6 mg/200 gBB; 7,2 mg/200 gBB; 14,4 mg/200 gBB tikus berurutan. Uji statistik dengan menggunakan uji korelasi dan ANOVA satu arah menunjukkan bahwa pemberian Sun Chlorella 7,2 mg dan 14,4 mg meningkatkan kadar SOD pada tikus yang diinduksi $\mathrm{CCl}_{4}$ secara bermakna $(\mathrm{p}=0,004 ; \mathrm{p}=0,009)$. Kadar SOD berhubungan kuat dengan kadar aspartat aminotransferase/ AST $(\mathrm{r}=-0,685 ; \mathrm{p}=0,000)$ dan alanin aminotransferase/ALT $(\mathrm{r}=-0,659 ; \mathrm{p}=0,000)$. Kesimpulan penelitian ini adalah pemberian Sun Chlorella meningkatkan kadar SOD pada tikus yang diinduksi $\mathrm{CCl}_{4}$. Peningkatan kadar SOD menyebabkan penurunan kadar AST dan ALT.
\end{abstract}

Kata kunci: Antioksidan, $\mathrm{CCl}_{4}$, Chlorella, $\mathrm{SOD}$

Received: 30 June 2020; Revised: 11 February 2021; Accepted: 8 April 2021; Published: 30 April 2021

Correspondence: Wahyu Siswandari. Department of Clinical Pathology, Faculty of Medicine, Universitas Jenderal Soedirman. Jln. Dr. Gumbreg No. 1, Mersi, Purwokerto 53112, Central Java, Indonesia. E-mail: wahyu_swdr@yahoo.com, wahyu.siswandari@ unsoed.ac.id 


\section{Introduction}

The liver is an organ essential in the metabolism and detoxification of foreign substances in the body, such as carcinogens, chemicals, drugs, and insecticides. ${ }^{1,2}$ These substances can cause damage to hepatocyte cells in the liver. ${ }^{3}$ One of the chemicals that can impair the liver is carbon tetrachloride $\left(\mathrm{CCl}_{4}\right)$, which increases lipid peroxidation and hepatocyte death marked by swelling, vacuolization, and hepatocyte in rats. ${ }^{4,5}$ It also promotes cirrhotic change. ${ }^{6}$ Therefore, induction of $\mathrm{CCl}_{4}$ in experimental animals is often used in research. ${ }^{6,7}$

Various drugs, natural ingredients, or organisms have been developed to reduce liver damage due to chemicals and infections. One of the organisms used to resolve liver damage is Chlorella sp. ${ }^{8}$ Chlorella is a unicellular green alga that contains various antioxidants such as chlorophyll, essential amino acids, protein, minerals, vitamins, dietary fiber. ${ }^{9}$ It also contains phytochemical composition such as alkaloids, flavonoids, triterpenes, glycosides, tannins, and phenols. ${ }^{10}$ Carotenoid is one of the substances in Chlorella sp., which plays a role as an antioxidant. ${ }^{11}$

Many studies of Chlorella sp. have been extensively researched. Lee et al. ${ }^{7}$ (2010) showed that the administration of Chlorella supplements to smokers has antioxidant effects. Azocar and $\operatorname{Diaz}^{12}$ (2013) found that replenishment of Chlorella can reduce aspartate aminotransferase levels in adult chronic hepatitis $\mathrm{C}$ patients. Cai et al. $^{13}$ (2015) showed that Chlorella vulgaris extract led to a significant decrease in aspartate aminotransferase (AST) and alanine aminotransferase (ALT) in rats, followed by an increased antioxidant activity such as superoxide dismutase (SOD), catalase, and glutathione (GSH), which compared to the $\mathrm{CCl}_{4}$ induced rats. ${ }^{12,13}$

This study aims to explore hepatoprotective effects of Sun Chlorella (CNI Sun Chlorella; PT Citra Nusa Insan Cemerlang [PT CNI], Jakarta, Indonesia) based on antioxidant status, specifically in levels of superoxide dismutase (SOD) in Rattus norvegicus carbon tetrachloride $\left(\mathrm{CCl}_{4}\right)$ induced rats. This study differs from Cai et al. ${ }^{13}$ in model animals for $\mathrm{CCl}_{4}$ and Chlorella dosage and treatment duration.

\section{Methods}

This research was conducted in Animal House and Research Laboratory, Faculty of Medicine, Universitas Jenderal Soedirman, Purwokerto, from November 2016-January 2017.

Thirty male white rat Wistar strain with $2-3$ months of age and 200-250 g of weight from LPPT IV Universitas Gadjah Mada Yogyakarta was used in this study. Ethics approval for this research was issued by the Research Ethics Committee, Faculty of Medicine, Universitas Jenderal Soedirman, Purwokerto No. 176/ KEPK/X/2016.

The Chlorella preparation used in this study was the Sun Chlorella tablet produced by PT CNI (SD 081534191), which contained $170 \mathrm{mg}$ of Chlorella powder extracted from Chlorella pyrenoidosa. This Sun Chlorella was chosen because it is widely available and has been commonly used as a health supplement.

This research was conducted experimentally with a completely randomized and post-test only with a control group design. The rats were divided into five groups, namely $\mathrm{K}_{1}, \mathrm{~K}_{2}, \mathrm{~K}_{3}, \mathrm{~K}_{4}$, $\mathrm{K}_{5}$, and were acclimated within seven days. The negative control group (K1) were given aquades, the positive control group (K2) were given $\mathrm{CCl}_{4}$ (Merck, Sigma-Aldrich 289116); $\mathrm{CCl}_{4}+$ Chlorella $3.6 \mathrm{mg}$ (K3 group); $\mathrm{CCl}_{4}+$ Chlorella $7.2 \mathrm{mg}\left(\mathrm{K}_{4}\right.$ group); $\mathrm{CCl}_{4}+$ Chlorella $14.4 \mathrm{mg}$ ( $\mathrm{K}_{5}$ group). Aquades or $\mathrm{CCl}_{4}$ were given orally with a gastric probe at a dose of $0.2 \mathrm{~mL} / 100 \mathrm{~g}$ of body weight (BW) two times a week for two weeks, followed by $0.1 \mathrm{~mL} / 100 \mathrm{gBW}$ two times a week for two weeks. Sun Chlorella (CNI Sun Chlorella) was given orally with a gastric probe at a dose of $3.6 \mathrm{mg}$ or $7.2 \mathrm{mg}$ or $14.4 \mathrm{mg} / 200 \mathrm{gBW}$ for four weeks. ${ }^{14}$ Chlorella dose of $7.2 \mathrm{mg} / 200$ gBW was obtained from converting an adult human dose to $400 \mathrm{mg} / 70 \mathrm{~kg}$. Next, the dose was divided by two $\left(3.6 \mathrm{mg}\right.$ ) and multiply by two $(14.4 \mathrm{mg}) .^{15}$

Blood collection was done through the orbitalis vein of the rat one day after the treatment. Furthermore, the blood was centrifuged at a speed of $4.000 \mathrm{rpm}$. The blood serum was then separated from erythrocytes, and then AST, ALT, and SOD were examined.

AST (DiaSys 126019910920), ALT (DiaSys 127019910026), and SOD (Randox SD126) levels were examined using a spectrophotometer (Shimadzu UV 1800). The data obtained were 
analyzed using a correlation test and one way ANOVA multivariate test. One data from the $\mathrm{K}_{3}$ group was excluded because it was an outlier.

\section{Results}

The mean levels of AST, ALT, and SOD in various treatment groups are presented in Table 1. AST, ALT, and SOD levels have normal data distribution ( $p>0.05)$, but the homogeneity of
AST and ALT variance showed different variants. The highest mean levels of AST $(3,210.00 \mathrm{U} / \mathrm{L})$ and ALT (2,616.66 U/L) were acquired in the K2 group, the group with $\mathrm{CCl}_{4}$ administration, while the highest mean levels of SOD $(73.00 \mathrm{U} / \mathrm{mL})$ was in the negative control group (K1).

The results showed that administration of $\mathrm{CCl}_{4}$ increased AST levels from 267.33 U/L to $3,210.00 \mathrm{U} / \mathrm{L}(\mathrm{p}=0.027)$. Sun Chlorella at either dose of $3.6 \mathrm{mg}, 7.2 \mathrm{mg}$, or $14.4 \mathrm{mg} / 200 \mathrm{gBW}$ did

Table 1 AST, ALT, and SOD Levels in Experimental Animals

\begin{tabular}{cccc}
\hline Groups & $\begin{array}{c}\text { AST } \\
(\mathbf{U} / \mathbf{L})\end{array}$ & $\begin{array}{c}\text { ALT } \\
\mathbf{( U / L )} \\
\text { Mean }( \pm \mathbf{S D})\end{array}$ & $\begin{array}{c}\text { SOD } \\
(\mathbf{U} / \mathbf{m L})\end{array}$ \\
\hline $\mathrm{K} 1$ & $267.33(99.32)$ & $233.83(135.24)$ & $73.00(4.42)$ \\
$\mathrm{K} 2$ & $3,210.00(154.07)$ & $2,616.66(1,105.72)$ & $37.83(4.95)$ \\
$\mathrm{K} 3$ & $821.20(477.84)$ & $886.00(716.34)$ & $40.00(3.74)$ \\
$\mathrm{K} 4$ & $1,385.00(643.60)$ & $1,110.00(503.65)$ & $48.50(2.94)$ \\
$\mathrm{K} 5$ & $947.50(646.85)$ & $795.83(621.38)$ & $66.00(5.58)$ \\
\hline
\end{tabular}

Table 2 Correlation between SOD Levels with AST and ALT Levels

\begin{tabular}{lcc}
\hline $\begin{array}{l}\text { AST and ALT } \\
\text { Levels }\end{array}$ & $\mathbf{r}^{*}$ & $\begin{array}{c}\text { Significance } \\
\text { (p) }\end{array}$ \\
\hline AST & -0.685 & 0.000 \\
ALT & -0.659 & 0.000 \\
\hline
\end{tabular}

Note: "Spearman's correlation not significantly reduce AST compared to the positive control group (respectively $\mathrm{p}=0.058$, $\mathrm{p}=0.160$, and $\mathrm{p}=0.073$ ).

$\mathrm{CCl}_{4}$ induced an increase in ALT from 233.83 $\mathrm{U} / \mathrm{L}$ to $2,616.66 \mathrm{U} / \mathrm{L}(\mathrm{p}=0.016)$. Sun Chlorella dose of $14.4 \mathrm{mg} / 200 \mathrm{gBW}$ significantly reduced ALT levels to $795.83 \mathrm{U} / \mathrm{L}$ compared to the positive control group (K2) with $\mathrm{p}=0.047$.

Table 3 ANOVA Test and Post Hoc Analysis of AST, ALT, and SOD Levels among Groups

\begin{tabular}{|c|c|c|c|c|c|c|}
\hline \multirow{2}{*}{ Groups } & \multicolumn{2}{|c|}{ AST } & \multicolumn{2}{|c|}{ ALT } & \multicolumn{2}{|c|}{ SOD } \\
\hline & ANOVA & Post Hoc & ANOVA & Post Hoc & ANOVA & Post Hoc \\
\hline & $0.000^{*}$ & & $0.000^{*}$ & & $0.000^{*}$ & \\
\hline K1 - K2 & & $0.027^{*}$ & & $0.016^{*}$ & & $0.000^{*}$ \\
\hline $\mathrm{K}_{1}-\mathrm{K}_{3}$ & & 0.235 & & 0.392 & & $0.000^{*}$ \\
\hline $\mathrm{K} 1-\mathrm{K}_{4}$ & & 0.039 & & $0.037^{*}$ & & $0.000^{*}$ \\
\hline $\mathrm{K} 1-\mathrm{K}_{5}$ & & 0.212 & & 0.313 & & 0.119 \\
\hline $\mathrm{K}_{2}-\mathrm{K}_{3}$ & & 0.058 & & 0.074 & & 1.000 \\
\hline K2 - K4 & & 0.160 & & 0.099 & & $0.004^{*}$ \\
\hline $\mathrm{K}_{2}-\mathrm{K}_{5}$ & & 0.073 & & $0.047^{*}$ & & $0.009^{*}$ \\
\hline $\mathrm{K}_{3}-\mathrm{K}_{4}$ & & 0.498 & & 0.973 & & $0.043^{*}$ \\
\hline $\mathrm{K}_{3}-\mathrm{K}_{5}$ & & 0.995 & & 0.999 & & $0.000^{*}$ \\
\hline $\mathrm{K}_{4}-\mathrm{K}_{5}$ & & 0.765 & & 0.866 & & $0.000^{*}$ \\
\hline
\end{tabular}

Note: *the mean difference is significant at the 0.05 level 
SOD levels in experimental animals decreased from $73.00 \mathrm{U} / \mathrm{mL}$ to $37.83 \mathrm{U} / \mathrm{mL}$ due to $\mathrm{CCl}_{4}$ administration $(\mathrm{p}=0.000)$. Sun Chlorella tablet given at a dose of $7.2 \mathrm{mg}$ and $14.4 \mathrm{mg} / 200 \mathrm{gBW}$ significantly increased SOD levels $(\mathrm{p}=\mathrm{0.004}$ and $\mathrm{p}=0.009$ ) compared to the positive control group. The increase in SOD levels by Sun Chlorella administration dosed of $14.4 \mathrm{mg} / 200 \mathrm{gBW}$ approached the SOD levels of the healthy control group $(p=0.119)$. This study found a significant strong relationship between SOD levels with AST $(\mathrm{r}=-0.685, \mathrm{p}=0.000)$ and ALT levels $(\mathrm{r}=-0.659$, $\mathrm{p}=0.000)$.

\section{Discussion}

$\mathrm{CCl}_{4}$ is proven to cause damage to liver cells, which is observed from increased AST and ALT levels. The highest AST and ALT levels were found in the positive control group that received $\mathrm{CCl}_{4}$ only. Adipocytokine adiponectin ${ }^{16}$ mediates liver injury by $\mathrm{CCl}_{4}$ through bioactivation of endoplasmic reticulum and mitochondrial centrilobular hepatocytes, which contain many cytochrome P450 2E1 (CYP2E1). This mechanism cause trichloromethyl $\left(\mathrm{CCl}_{3}\right)$ and trichloromethyl peroxyl $\left(\mathrm{CCl}_{3} \mathrm{OO}\right)$ free radicals to activate haloalkylation of cell macromolecules. Cell destruction due to $\mathrm{CCl}_{3}$ can occur anaerobically or aerobically. The anaerobic process is in the form of dimerization of $\mathrm{CCl}_{3}$ to form hexachloroethane. $\mathrm{CCl}_{3}$ can also bind directly to lipids and microsomal proteins and the heme part of CYP450. The aerobic process causes $\mathrm{CCl}_{3}$ to bind to oxygen to form trichloromethyl peroxyl $\left(\mathrm{CCl}_{3} \mathrm{OO}\right)$. $\mathrm{CCl}_{3} \mathrm{OO}$ can bind directly to tissue proteins or break down to form phosgene $\left(\mathrm{COCl}_{2}\right)$ and the electrophilic form of chlorine. $\mathrm{CCl}_{3}$ peroxy radical is the main initiator of lipid peroxidation that is formed from carbon tetrachloride exposure. This mechanism causes lipid peroxidation, which harms membrane integrity, decreased organelle function, and cell death. ${ }^{16-18}$

Hepatocyte cell death causes the release of enzymes, including AST and ALT enzymes. AST (around 80\%) comes from mitochondria and $20 \%$ from the cytoplasm of liver cells. ALT is an indicator of liver cell damage enzymes, mainly produced by the cytoplasm of liver cells. Increased ALT and AST are found in liver damage. ${ }^{19}$ The results of this study indicate that liver cell damage occurs in experimental animals due to $\mathrm{CCl}_{4}$ induction based on an increase in AST and ALT levels. The result of this study is consistent with some previous studies. AbouGabal et al. ${ }^{20}$ found a significant increase in AST and ALT levels in the group given only $\mathrm{CCl}_{4}(1 \mathrm{~mL} / \mathrm{kgBW}$ mice/ day for three weeks) compared to the control and olive oil groups. Likewise, the research of Fortea et al. ${ }^{21}$ showed an increase in AST and ALT levels in the group given $\mathrm{CCl}_{4}$ twice a week for 12 weeks compared with the control group. Ito et al., ${ }^{22}$ Song et al., ${ }^{23}$ El-Bialy et al., ${ }^{24}$ El-Dakhly et al. ${ }^{25}$ also reported a significant difference in AST and ALT level between $\mathrm{CCL}_{4}$ and control group. $\mathrm{CCl}_{4}$ induction treatment for four weeks is likely to cause chronic liver damage, which is observed from an increase in AST levels higher than ALT. ${ }^{19}$

This study shows that Chlorella can increase SOD antioxidant and decrease AST and ALT levels in Rattus norvegicus rats administered by carbon tetrachloride $\left(\mathrm{CCl}_{4}\right)$. These results are similar to the previous studies. Cai et al. ${ }^{13}$ reported that pigment-protein complex (PPC) was isolated from Chlorella vulgaris effectively restored SOD level. Research by Sikiru et al. ${ }^{26}$ in the white rabbit showed the highest levels of SOD found in the group given Chlorella vulgaris supplements at a dose of $200 \mathrm{mg} / \mathrm{gBW}$. Another study showed that the administration of $5 \mathrm{mg} / 100 \mathrm{gBW}$ of Chlorella vulgaris extract could increase SOD activity to protect liver cells' damage caused by $\mathrm{CCl}_{4}$ exposure. ${ }^{27}$ Decreased AST and ALT levels are similar with research results from Cai et al. ${ }^{13}$ and Ito et al. ${ }^{22}$ Another study proved that Chlorella could reduce AST and ALT level in acetaminophen-induced liver damage rat model. ${ }^{28}$

The carotenoid content in Chlorella probably causes an increase in SOD levels. ${ }^{11}$ Carotenoids are known to have antioxidant functions that significantly reduce free radicals and activate oxidative compounds. Carotenoid content in the form of B-carotene or astaxanthin prevents the oxidation of cells by free radicals through scavenging free radicals to prevent and stop the oxidative reaction chain. The protective mechanism by $\beta$-carotene in cells against oxidative reactions is by preventing the formation of oxygen singlets. Singlet oxygen is a non-electrophilic radical ROS that is easily bonded with organic molecules, affecting the oxidation process by directly attacking electronrich compounds without the involvement of free radicals. B-carotene is also efficient as an oxygen scavenger, reducing ROS release, which decreases in microsomal and cytochrome p450, 
prevents chain reactions, or damages the lipid peroxidation reaction. ${ }^{27,29,30}$

This study found a significant relationship between SOD levels with AST and ALT. The increase in SOD levels would reduce AST and ALT levels. It proves that Chlorella has a hepatoprotective effect. In vivo research by Cai et al., ${ }^{13}$ the administration of protein pigment complexes taken from Chlorella showed a hepatoprotective effect. This hepatoprotective effect is expected from the carotenoid content in Chlorella, which can inhibit and bind ROS..$^{11,30}$

\section{Conclusions}

$\mathrm{CCl}_{4}$ induction cause liver damage, as shown by increased levels of AST and ALT. Chlorella administration has a hepatoprotective effect in $\mathrm{CCl}_{4}$-induced Rattus norvegicus rats based on increased SOD levels, decreased AST and ALT levels.

\section{Conflict of Interest}

The authors state that there is no conflict of interest.

\section{References}

1. Brunt EM, Tiniakos DG. Histopathology of nonalcoholic fatty liver disease. World $\mathbf{J}$ Gastroenterol. 2010;16(42):5286-96.

2. Murray RK, Daryl KG, Victor WR. Biokimia Harper. 27 $7^{\text {th }}$ Edition. Jakarta: EGC; 2012.

3. Moore KL, Dalley AF, Agur AMR. Moore clinical oriented anatomy. $7^{\text {th }}$ Edition. Philadelphia: Lippincott Williams \& Wilkins; 2014.

4. Adewale OB, Adekeye AO, Akintayo CO, Onikanni A, Sabiu S. Carbon tetrachloride $\left(\mathrm{CCl}_{4}\right)$-induced hepatic damage in experimental Sprague Dawley rats: antioxidant potential of Xylopia aethiopica. J Phytopharmacol. 2014;3(2):118-23.

5. EL-Sayeda GE, EL-Sahar, Abor MMAE. Hepatotoprotective activity of different doses of Spirulina against $\mathrm{CCl}_{4}$ induced liver damage in rats. J Am Sci. 2012;8(8):916-23.

6. Scholten D, Trebicka J, Liedtke C, Weiskirchen R. The carbon tetrachloride model in mice. Lab Anim. 2015;49(Suppl 1):4-11.

7. Lee SH, Kang HJ, Lee HJ, Kang $\mathrm{MH}$,
Park YK. Six-week supplementation with Chlorella has favorable impact on antioxidant status in Korean male smokers. Nutrition. 2010;26(2):175-83.

8. Safafar H, van Wagenen J, Møller P, Jacobsen C. Carotenoids, phenolic compounds and tocopherols contribute to the antioxidative properties of some microalgae species grown on industrial wastewater. Mar Drugs. 2015;13(12):7339-56.

9. Andrade LM, Andrade CJ, Dias M, Nascimento CAO, Mendes MA. Chlorella and Spirulina microalgae as sources of functional foods, nutraceuticals, and food supplements; an overview. MOJ Food Process Technol. 2018;6(1):45-58.

10. Prabakarana G, Moovendhana M, Arumugam A, Matharasia A, Dineshkumara $\mathrm{R}$, Sampathkumar P. Quantitative analysis of phytochemical profile in marine microalgae Chlorella vulgaris. IJPBS. 2018;8(2):562-5.

11. Goiris K, Muylaert K, Fraeye I, Foubert I, Brabanter JD, Cooman LD. Antioxidant potential of microalgae in relation to their phenolic and carotenoid content. J Appl Phycol. 2012;24(6):1477-86.

12. Azocar J, Diaz A. Efficacy and safety of Chlorella supplementation in adults with chronic hepatitis $\mathrm{C}$ virus infection. World $\mathrm{J}$ Gastroenterol. 2013;19(7):1085-90.

13. Cai X, Yang Q, Wang S. Antioxidant and hepatoprotective effects of a pigment-protein complex from Chlorella vulgaris on carbon tetrachloride-induced liver damage in vivo. RSC Adv. 2015;2015;5(116):96097-104.

14. Constandinou C, Henderson N, Iredale JP. Modeling liver fibrosis in rodents. Methods Mol Med. 2005;117:237-50.

15. Halperin SA, Smith B, Nolan C, Shay J, Kralovec J. Safety and immunoenhancing effect of a Chlorella-derived dietary supplement in healthy adults undergoing influenza vaccination: randomized, doubleblind, placebo-controlled trial. CMAJ. 2003;169(2):111-7.

16. Lin SY, Xu D, Du XX, Ran CL, Xu L, Ren SJ, et al. Protective effects of salidroside against carbon tetrachloride $\left(\mathrm{CCl}_{4}\right)$-induced liver injury by initiating mitochondria to resist oxidative stress in mice. Int $\mathrm{J}$ Mol Sci. 2019;20(13):3187.

17. United States Environmental Protection Agency. IRIS toxicological review of carbon 
tetrachloride. Washington DC: United States Environmental Protection Agency; 2010.

18. Dutta S, Chakraborty AK, Dey P, Kar P, Guha $\mathrm{P}$, Sen S, et al. Amelioration of $\mathrm{CCl}_{4}$ induced liver injury in swiss albino mice by antioxidant rich leaf extract of Croton bonplandianus Baill. PLoS One. 2018;13(4):eo196411.

19. Rosenberg W, Badrick T, Sudeep T. Liver disease. In: Rivai N, Horvath AR, Wittwer CT, editors. Tietz textbook of clinical chemistry and molecular diagnostic. 6th Edition. Missouri. Elseiver; 2018. p. 1348-97.

20. AbouGabal AA, Aboul-Ela HM, Ali EM, Khaled AEM, Shalaby OK. Hepatoprotective, DNA damage prevention and antioxidant potential of Spirulina platensis on $\mathrm{CCl}_{4}$ induced hepatotoxicity in mice. Am J Biomed Res. 2015;3(2):29-34.

21. Fortea JI, Fernández-Mena C, Puerto M, Ripoll C, Almagro J, Bañares J, et al. Comparison of two protocols of carbon tetrachloride-induced cirrhosis in ratsimproving yield and reproducibility. Sci Rep. 2018;8(1):9163.

22. Ito H, Fujishima M, Okumura E, Nakada F, Ito H. Preventive effects of Chlorella pyrenoidosa (Chlorophyceae) of oral administration on carbon tetrachloride in experimentally induced liver injury of rats. Jpn Pharmacol Ther. 2019;47(7):1067-73.

23. Song W, Wu J, Yu L, Peng Z. Evaluation of the pharmacokinetics and hepatoprotective effects of phillygenin in mouse. Biomed Res Int. 2018;2018:7964318.

24. El-Bialy BE, El-Boraey NG, Hamouda
RA, Abdel-Daim MM. Comparative protective effects of Spirulina and Spirulina supplemented with thiamine against subacute carbon tetrachloride toxicity in rats. Biomed Pharmacol J. 2019;12(2):511-25.

25. EL-Dakhly SM, Salama AAA, Hassanin SOM, Yassen NN, Hamza AA, Amin A. Aescin and diosmin each alone or in low dose-combination ameliorate liver damage induced by carbon tetrachloride in rats. BMC Res Notes. 2020;13(1):259.

26. Sikiru AB, Arangasamy A, Alemede IC, Guvvala PR, Egena SSA, Ippala JR, et al. Chlorella vulgaris supplementation effects on performances, oxidative stress and antioxidant genes expression in liver and ovaries of New Zealand White rabbits. Heliyon. 2019;5(9):e02470.

27. Hernayanti, Simanjuntak SBI. Antioxidant effect of Chlorella vulgaris on physiological response of rat induced by carbon tetrachloride. Biosaintifika. 2019;11(1):8490.

28. Vasudevan SK, Seetharam S, Poongavanam A. Evaluation of detoxifying activity of ORGCHP against acetaminophen induced hepatotoxicity in Sprague Dawley rats. IJBCP. 2020;9(6):912-8.

29. Fiedor J, Burda K. Potential role of carotenoids as antioxidants in human health and disease. Nutrients. 2014;6(2):466-88.

30. Abd El Baky HH, El-Baroty GS. Healthy benefit of microalgal bioactive substances. J Aquatic Sci. 2013;1(1):11-23. 